\title{
Antecedents and Consequences of Work Stress Behavior
}

\author{
Nuria Universari ${ }^{1}$, Mugi Harsono ${ }^{2}$ \\ ${ }^{1}$ Semarang University \\ ${ }^{2}$ University of Sebelas Maret
}

\begin{abstract}
The purpose of this paper is to obtain a work stress model from scientific literature published from 2017 to 2020, where in one of the years, 2020, there was a covid-19 pandemic which had an impact on work stress. This study uses a literature review on work stress including antecedents, consequences, work stress management and the type of work/profession studied in research on work stress from 2017 to 2020. Based on the results of literature studies, the antecedents that most often appear in research on work stress are role conflict, workload, and leadership, while the consequences that often arise are burnout, job satisfaction/dissatisfaction, and intentions turnover. Work stress management involves individual and organizational levels. While the profession that has been mostly researched on the topic of work stress are paramedics and employees of the banking industry.
\end{abstract}

Keywords: work stress; antecedents; consequences; work stress management; profession

\section{INTRODUCTION}

Word stress comes from the Latin "stringere" which means "to pull tight". Seyle (1936) in Burman (2018) defines stress as a syndrome produced by various harmful agents. Seyle (1936) also describes stress as a non-specific response from the body to harmful stimuli. Stress occurs when there are demands from someone that exceeds the resources they have (Lazarus, 1976 in Burman, 2018).

Work stress arises because of environmental demands and different responses for each individual in dealing with these demands. Environmental demands that trigger work stress has developed. For example, the Covid-19 pandemic emergency that occurred during 2020 raised concern for many people who reported anxiety, depression, and stress, especially when they were already suffering from poor health (Brokks et al., 2020; Wang et al., 2020). This paper tries to add to the work stress literature based on articles published in the last four years, namely 2017-2020, wherein one of the years, namely 2020, the Covid-19 pandemic has occurred which has an impact on work stress for certain types of work. Through a literature study with a sample of articles for the last four years, it is hoped that a model of work stress can be obtained from scientific literature published in the last four years (from 2017 to 2020). The discussion about job stress consists of four parts. The first part attempts to explore the antecedents of job

\footnotetext{
1Email: nuria@usm.ac.id

2*Corresponden Author, Email: mugiharsono fe@staff.uns.ac.id

P-ISSN: 2580-6084, E-ISSN: 2580-8079
} 
stress, the second part presents the consequences of work stress, the third part discusses the management of work stress and the fourth part deals with the types of work studied in research on job stress.

\section{THEORETICAL BACKGROUND}

Based on historical literature, the term stress has been re-created in the form of a term that can be used to describe the force that produces or causes deformation (Harshana, 2018). When referring to organizations, the concept of stress is always accompanied by several definitions such as performance, motivation, and employee welfare. People experience stress in different ways and for different reasons (Kundaragi and Kadako, 2015). Reactions are based on perceptions about an event or situation. Distress is a form of stress that views a situation negatively so that people feel depressed. Meanwhile, eustress is a form of stress as a result of a positive view of an event or situation, so that people do not feel depressed but feel challenged to do good.

Work stress is considered an important problem for organizations because it tends to contribute to organizational inefficiency, high turnover rates, absence due to illness, decreased quality and quantity of work operations, increased health care costs, and decreased job satisfaction and performance (Kar and Mishra, 2016). Job-related stress occurs when there is a mismatch between job demands and individual workers' resources and ability to meet these demands. Work-related stress can be defined as a negative psychological state with cognitive and emotional components that affect the health of individuals and groups (Hassard and Cox, 2011 in Redin and Erro-Garces, 2020). Luthans (2006) in Kar and Mishra (2016) defines stress as a response to certain situations or conditions that are determined by individual differences and psychological processes, as a consequence of environmental actions, situations, or events that place too many demands on a person's psychological and physical domains.

\section{METHOD, DATA AND ANALYSIS}

This research uses a qualitative approach. The collection of data and information in this study was carried out by using the literature review technique. This technique is done by reading, studying, and reviewing literature related to work stress. The literature 
review for this research is in the form of journal articles on job stress published in the last four years, from 2017 to 2020 .

\section{RESULTS}

\section{Antecedents of Work Stress}

Research on work stress tries to explore the causes of stress to overcome the losses caused by the emergence of stress. Antecedents of job stress can come from individuals or organizations. Some of the antecedents of work stress that were used during the 2017 to 2020 study and which the authors identified successfully will be presented below.

The variables identified are antecedents of work stress and are factors that come from individuals, namely fear of the unknown (Sahni, 2020), self-efficacy (Hu et al., 2019, Park and Jang, 2017), organizational citizenship behavior/ OCB (Rabenu et al., 2017), and emotional intelligence (Revzani and Pouria, 2019). In the research of $\mathrm{Hu}$ et al. (2019), self-efficacy plays a role as a mediation for the influence of leadership pressure on work stress, whereas Park and Jang's research (2017) shows a negative relationship between self-efficacy and stress. Research by Rabenu et al. (2017) examined the role of OCB as an independent variable and as a mediator variable. There is a negative relationship between OCB and work stress and it is found that there is an indirect effect of organizational justice on work stress that is mediated by OCB. The more organizational justice is felt, the more likely it is that OCB will increase. The increase in OCB further reduces work stress. Emotional intelligence in the research of Revzani and Pouria (2019) hurts work stress.

Antecedents of work stress originating from roles in the organization have been identified as producing work stress to a certain extent. Some of the antecedents of work stress that come from roles in organizations found in this literature study are role conflict (Harry, 2020; Naoum et al., 2018; Soelton et al., 2019; Yang et al., 2019), role ambiguity (Amirudin, 2019; Harry, 2020), distribution/management of responsibilities (Galanis et al., 2018; Hampton et al., 2019), and work obligations (Kongcharoen et al., 2019).

Antecedents of work stress originating from work itself include workload (Harry, 2020; Oruh et al., 2020; Pandey, 2020; Sidhu et al., 2020), work environment 1Email: nuria@usm.ac.id 
(Oruh et al., 2020; Sidhu et al., 2020), work intensification (Walker, 2020), administrative/organizational pressure (Allison et al., 2019), work/job involvement (Li et al., 2018, Park and Jang, 2017), work demands (Wijewardena et al., 2020), time pressure ( Amirudin, 2019), working conditions (Goswami et al., 2019), evaluation and performance appraisal systems (Pandey, 2020) and the uncertainty of working conditions (Hampton et al., 2019).

Antecedents of work stress can also come from organizational relationships with external parties, namely how the suitability of family demands versus organizational demands and between personal interests versus organizational policies. Some antecedents originating from organizational relationships with outsiders can be identified, namely family-role conflicts (Amirudin, 2019; Li et al., 2018), family role overload (Park and Jang, 2017), and work-life conflicts (Foy et al., 2018). In addition, job stress can be caused by career development, namely the career development environment (Naoum et al., 2018).

Relationships in the organization are a source of work stress. In the literature study conducted by the author, the antecedents of work stress are related to relationships in organizations including organizational structure (Naoum et al., 2018), leadership (Elomaa et al., 2020; Manoppo, 2020; Paeveen and Adeinant, 2019; Yao et al., 2020), social support (Bjaalid, 2020; Foy et al., 2018; Yousaf et al., 2020), communication and management support (Pandey, 2020; Sahni, 2020), culture high power distance (Hampton et al., 2019; Oruh et al., 2020), autonomy (Patel and Wolfe, 2019) and work team coordination (Hampton et al., 2019).

Sources of work stress can also come from physical and physical threats and violence at work (Allison et al., 2019; Rasool et al., 2020), financial problems (Kongcharoen et al., 2019), delays in information (Ajayi et al., 2019), the use of digital technology (Rafida, 2020), countermeasures, resilience extraversion, awareness and neuroticism (Duschek et al., 2019), personal relationships outside of work and lack of free time for family and friends (Galanis et al., 2018), customer misbehaviors (Hu et al., 2017), customer abusive behaviour (Kashif et al., 2017) psychological empowerment (Tripathi and Bharadwaja, 2018) and spirituality at work (Saxena et al., 2020). Some of the antecedent variables of work stress have never been studied in previous studies, thus 
adding to the research literature on work stress. A summary of the antecedents of work stress can be seen in Table 1 .

Table 1. Antecedents of Work Stress

\begin{tabular}{cll}
\hline No & \multicolumn{1}{c}{ Antecedents of Work Stress } & \multicolumn{1}{c}{ Researcher } \\
\hline 1. & Individual Factors & \\
& Unrecognized fear & Sahni, 2020 \\
& Self efficacy & Hu et al., 2019; Park and Jang, \\
& 2017 \\
& Organizational Citizenship Behavior & Rabenu et al., 2017 \\
& Emotional Intelligent & Revzani and Pouria, 2019 \\
Burnout & Soelton et al., 2019
\end{tabular}

2. Organizational Factors
a. Role in organization
Role conflict

Role ambiguity

Responsibility distribution/

management

Work obligations

b. Work

Workload

Work environment

Work intensification

Administrative/organizational

pressure

Work/job involvement

Work demands

Time pressure

Working conditions

Evaluation and performance

appraisal system

Uncertainty of working

conditions

c. Organizational Relations with

Outsiders

Family-role conflict

Family role overload

Work-life conflict

d. Career development

Career development environment
Harry, 2020; Naoum et al., 2018;

Soelton et al., 2019; Yang et al., 2019;

Amirudin, 2019; Harry, 2020

Galanis et al., 2018; Hampton et

al, 2019

Kongcharoen et al., 2019

Harry, 2020; Oruh et al., 2020;

Pandey, 2020; Sidhu et al., 2020

Oruh et al., 2020; Sidhu et al., 2020

Walker, 2020

Allison et al., 2019

Li et al., 2018; Park and Jang, 2017

Wijewardena et al., 2020

Amirudin, 2019

Goswami et al., 2019

Pandey, 2020

Hampton et al., 2019

Amirudin, 2019; Li et al, 2018

Park and Jang, 2017

Foy et al., 2018 
e. Relationships in organizations

Organizational Structure

Leadership

Social support

Communication and management support

High power distance culture

Autonomy

Work team coordination

3. Other antecedents

Physical and psychological threats and violence at work

Financial problems

Delay in information

Use of digital technology

Countermeasure, extraversioan

resilience, awareness and

neuroticism

Personal relationships outside of work and lack of free time for family and friends

Customer misbehaviors

Customer abusive behaviour

Psychological empowerment

Spirituality at work
Naoum et al., 2018

Elomaa et al., 2020; Manoppo,

2020; Paeveen and Adeinant,

2019; Yao et al., 2020

Bjaalid, 2020; Foy et al., 2018;

Yousaf et al., 2020

Pandey, 2020; Sahni, 2020

Hampton et al., 2019; Oruh et al., 2020

Patel and Wolfe, 2019

Hampton et al., 2019

Allison et al., 2019; Rasool et al., 2020

Kongcharoen et al., 2019

Ajayi et al., 2019

Rafida, 2020

Duschek et al, 2019

Galanis et al., 2018

Hu et al., 2017

Kashif et al., 2017

Tripathi and Bharadwaja, 2018

Saxena et al., 2020

Source: processed and developed in thid study (2021)

\section{The Consequences of Work Stress}

The consequences of work stress can be seen from both the individual and the organizational side. From the individual side, there are several changes that individuals feel when experiencing pressure or tension related to work, namely physical reactions, emotions, thoughts, and behavior. Changes occur in physical conditions to the emergence of various health problems, for example, the consequences of work stress in the studies that are made into the literature by the author, namely health damage (Petek, 2018; Sidhu et al., 2020), mental health and psychopathological symptoms (Fortes et al., 2020), emotional exhaustion (Kashif et al., 2017; Peasley et al., 2020) and burnout/fatigue (Chen, 2020; Park et al., 2020 Parveen and Adeinat, 2019). This has an 
impact on the incidence of individual costs (Molek-Winiarska and Molek Kozakowska, 2020)

Changes that occur at the individual level will affect attitudes towards work. Employees will feel bored and show stress symptoms known as burnout. When experiencing burnout, people will show absenteeism from work or increased absenteeism. Some of the antecedents of job stress related to attitudes towards work in the observed literature include job dissatisfaction/satisfaction (Darte-Baah, 2019; Heyder, 2019; Pandey, 2020; Park and Jang, 2017), reduced personal achievement and depersonalization (Peasley et al., 2020), career satisfaction, performance role and extrarole performance (Nisar and Rasheed, 2019), work motivation (Kongcharoen et al., 2019) intention turnover (Park et al., 2020; Yousaf et al., 2020), and job involvement (Klein et al., 2019).

In stressful conditions, employees will decrease their productivity according to the U curve. This means that optimal pressure will encourage optimal performance. Meanwhile, the pressure is low or the pressure is too big, the performance will decrease. So that job stress has consequences on task performance (Naoum et al., 2018, Petek, 2018). Poor job performance by employees will cause inefficiency in organizational performance. Other consequences of work stress are work-family conflict (Rabenu et al., 2017), perceived organizational support (Saadeh and Suifan, 2020), and maturity to manage knowledge (Marques et al., 2020). A summary of the consequences of work stress can be seen in Table 2 .

Table 2. Consequences of Work Stress

\begin{tabular}{cll}
\hline No & \multicolumn{1}{c}{ Consequences of Work Stess } & \multicolumn{1}{c}{ Researches } \\
\hline 1. & Individual Factors & \\
& Health damage & \\
Mental impairment and & Petek, 2018; Sidhu et al., 2020 \\
psychopathological symptoms & Fortes et al., 2020 \\
Emotional exhaustion & \\
& Kashif et al., 2017; Peasley et al., \\
Fatique/burnout & 2020 \\
& Chen, 2020; Klein et al., 2019; \\
& Park et al., 2020; Parveen and \\
& Adeinat, 2019 \\
& Molek-Winiarska and Molek \\
& Kozakowska, 2020 \\
\hline
\end{tabular}

1Email: nuria@usm.ac.id 
2. Organization

Work dissatisfaction/satisfaction

Darte-Baah, 2019; Heyder, 2019;

Pandey, 2020; Park and Jang,

2017

Reduced personal accomplishment

Peasley et al., 2020

and depersonalization

Career satisfaction, role performance Nisar and Rasheed, 2019

and extra role performance

Work motivation

Kongcharoen et al., 2019

Turnover intention

Park et al., 2020; Soelton et al., 2019; Yousaf et al., 2020

Work involvement

Klein et al., 2019

3. Another consequence

Task performance

Naoum et al., 2018, Petek, 2018

Work-family conflict

Rabenu et al., 2017

Perceived organizational support

Saadeh and Suifan, 2020

Maturity to manage knowledge

Marques et al., 2020

Source: processed and developed in this study (2021)

\section{Management of Work Stress}

Stress as the pressure at work at a certain level can cause morale (eustress), but if the pressure is excessive or less pressure will cause negative stress (distress). Efforts to manage stress become important with the principle of how to manage negative stress into positive stress so that threats can be modified into challenges.

Broadly speaking, efforts to manage stress can be grouped into two types of strategies, namely coping strategies at the individual level and strategies at the organizational level (Moorhead and Griffin, 1995).

Individual-level strategies found in this literature study include relaxation methods (Bennion et al., 2018), coping strategies that focus on avoiding and decreasing sleep quality, physical exercise and family/friend support (Galanis et al., 2018), and strategies spiritual coping through mindfulness meditation/prayer (Walker, 2020).

Strategies for managing work stress at the organizational level can use additional tools such as communication systems and software, access to psychological services, change in leadership, provision of resources for employee welfare such as job training, and better work team coordination (Hampton et al., 2019). In addition, organizations can conduct psychological suggestion training (Chen, 2020) as well as psycho-social support, community support, and an effective system of organizational support (Sahni, 2020). A summary of work stress management can be seen in Table 3.

1Email: nuria@usm.ac.id

2*Corresponden Author, Email: mugiharsono fe@staff.uns.ac.id

P-ISSN: 2580-6084, E-ISSN: 2580-8079 
Table 3. Work Stress Management

\begin{tabular}{lll}
\hline No & Work Stress Management \\
\hline $1 . \quad$ Individual Level & Relaxation method \\
& Coping strategy that focuses on avoiding \\
& and decreasing the quality of sleep, \\
& physical exercise and family/friend \\
& support \\
& Spiritual coping strategies through \\
& mindfulness meditation/prayer \\
& Communication system \\
& Access to service psychological \\
& Change in leadership \\
& Resource provision (job training, \\
& psychological suggestion training), \\
& psycho-social support, community \\
& support, organizational support, \\
& work team coordination \\
&
\end{tabular}

Source: processed and developed in this study (2021)

\section{Types of Work Researched in Research on Work Stress}

Research in the literature observed by the authors shows that work stress is studied in various types of work. Observations show that research on work stress is carried out in the construction professional profession (Ajayi et al., 2019; Hampton et al., 2019; Naoum et al., 2018), the police (Allison et al., 2019; Li et al., 2018; Nisar and Rasheed, 2019), teachers and headmaster (Heyder, 2019; Hu et al., 2019; Kongcharoen et al., 2019; Walker, 2020), Paramedics (Bjaalid, 2020; Duschek et al., 2019; Klein et al., 2019; Manoppo, 2020; Park et al., 2020; Rasool et al., 2020; Saadeh and Suifan, 2020; Zaghini et al., 2020), hotel industry employees (Goswani et al., 2019; Yousaf et al., 2020) and banking industry employees (Darte-Baah, 2019; Kashif et al., 2017; Oruh et al., 2020; Pandey, 2020; Parveen and Adeinat, 2019; Tripathi and Bharadwaja, 2018; $\mathrm{Wu}, 2020$;).

Some professions are only studied by one researcher, for example in the profession of daycare leader (Elomaa et al., 2020), library staff (Petek, 2018), the salesperson (Peaslay et al., 2020), women micro-entrepreneurs (Wijewardena et al.., 2020), auditors (Amirudin, 2019), immigration officers (Yang et al., 2019), employees in the electricity sector (Sidhu et al., 2020), lecturers (Rafida, 2020), cabin crewmembers (Hu et al., 2017) and sales agents (Park and Jang, 2017). Besides that, some studies do not specifically mention the professions of research subjects regarding 
this work stress. For example, researchers only mention that the research subjects are white-collar workers (Nappi et al., 2020) and company employees (Harry, 2020; Yao et $a l ., 2020)$. A summary of the types of professions studied in research on work stress can be seen in Table 4.

Table 4. Summary of Professions in The Work Stress Research

\begin{tabular}{clc}
\hline No & \multicolumn{1}{c}{ Type of Profession } & $\begin{array}{c}\text { Number of } \\
\text { Research }\end{array}$ \\
\hline 1. & Construction professionals & 3 \\
2. & Teachers and headmaster & 4 \\
3. & Police & 3 \\
4. & Paramedics & 8 \\
5. & Hotel industry employees & 2 \\
6. & Banking industry employees & 7 \\
7. & Daycare leader & 1 \\
8. & Female micro entrepreneurs & 1 \\
9. & Library staff & 1 \\
10. & Auditor & 1 \\
11. & Immigration officers & 1 \\
12 & Employees in the electricity sector & 1 \\
13. & Lecture & 1 \\
14. & Cabin crewmembers & 1 \\
15. & Sales agents & 1 \\
\hline
\end{tabular}

Source: processed and developed in this study (2021)

\section{DISCUSSION}

Table 1 shows that antecedents that appear most frequently in research on Job stress are a conflict of roles, workload, and leadership. Each antecedent was used in four studies. Perrewé et al. (2012) in Henry (2020) states that role conflict refers to the mismatch of the requirements and expectations that employees receive from their supervisors or coworkers. The higher the role conflict, the higher the work stress. Workload and leadership factors are thought to be related to the Covid-19 pandemic. Research with workload antecedents was carried out in 2020 and research with leadership antecedents was carried out in 2020 as many as three studies. The Covid-19 pandemic has made changes in workload and leadership because the implementation of work from home which is carried out in almost all workplaces requires adaptation from employees and organizational leaders. 
Table 2 shows that the consequences that often arise are burnout (four studies), job dissatisfaction, and intentions turnover (three studies each). Burnout is a chronic affective response to stressful work conditions featuring high levels of interpersonal contact (Ganster and Schaubroeck, 1991). Research on burnout in the 1970s focused initially on specific professions such as nursing, social work, and teaching. The construct burnout extends to a variety of work fields that involve a certain level of interaction with other people such as the military, police, managers, librarians, and bluecollar workers. In research with consequences of burnout, the professions studied were paramedics and employees of the banking industry. In addition to burnout, job dissatisfaction and intentions are turnovers also a consequence of work stress that is the concern of researchers.

The results of a literature study on the management of work stress can be seen in table 3 The management of work stress can be grouped into two groups, namely management at the individual level and management at the organizational level. The two levels of work stress management must complement and support each other. When only one level is implemented without implementing the other levels, the results will not be optimal. Even the management of work stress is not successful.

In general, the results of research examining job stress in certain professions provide diversity in the types of professions studied. Many occupational professions have not been studied in terms of job stress. So that this becomes a challenge for researchers, especially in the field of behavioral sciences.

Table 4 also shows that the most researched professions on the topic of work stress are paramedics, namely eight studies, and banking industry employees, namely seven studies. This shows that work stress researchers are interested in making the paramedic profession and banking industry employees research subjects. The Covid-19 pandemic has become one of the factors that caused work stress for paramedics and banking industry employees so that a more in-depth study of work stress in these two professions is needed so that the research literature on work stress is wider.

\section{CONCLUSIONS}

Stress on individuals has an impact on individual performance, and in the end, will have an impact on the organization as a whole. Antecedents and consequences of 
job stress can come from individuals or organizations. Based on the results of literature studies, the antecedents that most often appear in research on work stress are role conflict, workload, and leadership, while the consequences that often arise are burnout, job satisfaction/dissatisfaction, and intentions turnover. Work stress management involves individual and organizational levels. The two levels of work stress management must complement and support each other.

Work stress can afflict employees of various professions. The professions that are mostly researched on the topic of work stress in this study are paramedics and employees of the banking industry. Work stress management is needed so that work stress can have good and beneficial consequences for employees of various professions, as well as for individuals and organizations.

\section{REFERENCES}

Ajayi, S. O., William, J. and Maria, U. (2019), “Occupational stress management for UK construction professionals Understanding the causes and strategies for improvement”, Journal of Engineering, Design and Technology, Vol. 17 No. 4, pp. 819-832.

Allison, P., Mnatsakanova A., McCanlies E., Fekedulegn D., Hartley T. A., Andrew M. E. and Volanti, J. M. (2020), "Police stress and depressive symptoms: role of coping and hardiness", Policing: An International Journal, Vol. 43 No. 2, pp. 247-261.

Amirudin, A., Pagalung G., Kartini and Arifuudin. (2019), "Mediating effect of work stress on the influence of time pressure, work-family conflict and role ambiguity on audit quality reduction behavior", International Journal of Law and Management.

Bennion, E., Olpin M. N. and DeBeliso M. (2018), “A comparison of 4 stress reduction modalities on measures of stress among university students", International Journal of Workplace Health Management.

Bjaalid, G., Olsen, E., Melberg, K. and Mikkelsen, A. (2020), "Institutional stress and job performance among hospital employees", International Journal of Organizational Analysis, Vol. 28, No. 2, pp. 365-382. 
Brooks, S.K., Webster, R.K., Smith, L.E., Woodland, L., Wessely, S., Greenberg, N., Rubin, G.J. (2020), "The psychological impact of quarantine and how to reduce it: Rapid review of the evidence”, Lancet, Vol. 395, pp. 912-920.

Burman, R. (2018), “A Systematic Literature Review of Work Stress”, International Journal of Management Studies, Vol. 5, Issue. 3, No. 9, pp. 112-132.

Caponnetto, P., Magro, R., Inguscio, L. and Cannella, M. C. (2018), "Quality of life, work motivation, burn-out and stress perceptions benefits of a stress management program by autogenic training for emergency room staff: A pilot study", Mental Illness, Vol. 10, No. 7913, pp. 67-70.

Chen, J. (2020), "Relationship Between Psychological Capital, Job Stress and Job Burnout of Special Education Workers", Revista Argentina de Clinica Psicological, Vol. 19, No. 1, pp. 1325-1331.

Clercq, D. E., Haq, I. U. and Azzem, M. U. (2019), "Time-related work stress and counterproductive work behaviour Invigorating roles of deviant personality traits", Personnel Review, Vol. 48 No. 7, pp. 1756-1781.

Dada, J. O., Babatunde, S. O., and Adeleye, R. O. (2019), “Assessment of academic stress and coping strategies among built environment undergraduate students in Nigerian higher education", Journal of Applied Research in Higher Education.

Dartey-Baah, K., Quartey, S. H., and Osafo, G. A. (2019), "Examining occupational stress, job satisfaction and gender difference among bank tellers: evidence from Ghana", International Journal of Productivity and Performance Management.

Duschek, S., Bair, A., Haux, S., Garrido, A. and Janka, A. (2020), "Stress in paramedics: relationships with coping strategies and personality traits", International Journal of Emergency Services, Vol. 9 No. 2, pp. 203-216.

Elomaa, M., Pakarinen, E, Eskel€a-Haapanen, S., Halttunen, L., Suchodoletz. A. V. and Lerkkanen, M. (2020), "Directors' stress in day care centers: related factors and coping strategies", International Journal of Educational Management, Vol. 34 No. 6, pp. 1079-1091.

Fortes, A. M., Tian, L. and Huebner, E. S. (2020), “Occupational Stress and Employees Complete Mental Health: A Cross-Cultural Empirical Study”, International Journal of Environmental Research and Public Health, Vol. 17.

\footnotetext{
1Email: nuria@usm.ac.id

2*Corresponden Author, Email: mugiharsono fe@staff.uns.ac.id

P-ISSN: 2580-6084, E-ISSN: 2580-8079
} 
Foy, T., Dwyer, R. J., Nafarrete, R., Hammoud, M. S. S. and Rockett, P. (2020), "Managing job performance, social support and work-life conflict to reduce workplace stress", International Journal of Productivity and Performance Management.

Galanis, P., Fragkou, D., Kaitelidou, D., Kalokairinou, A., and Katsoulas, T. A. (2018), "Risk factors for occupational stress among Greek police officers", Policing: An International Journal.

Ganster, D. C. and Schaubroeck, J. (1991), "Work stress and employee health”, Journal of Management, Vol. 17 No. 2, pp. 235-271.

Goel, M., and Verma, J. P. (2020), "Workplace stress and coping mechanism in a cohort of Indian service industry", Asia Pacific Management Review.

Goswami, I. and Dsilva, N. R. (2019), "Impact of job satisfaction and job stress on employees' life in Mumbai's hospitality sector An empirical study using SEM", Journal of Strategy and Management, Vol. 12 No. 3, pp. 330-346.

Hampton, P., Chinyio, E. A. and Riva, S. (2019), "Framing stress and associated behaviours at work An ethnography study in the United Kingdom", Engineering, Construction and Architectural Management, Vol. 26 No. 11, pp. 2566-2580.

Harris, E. G. and Fleming, D. E. (2017), “The productive service employee: personality, stress, satisfaction and performance", Journal of Services Marketing.

Harry, J. (2020), “Stress Management and Employee Performance”, European Journal of Human Resource Management Studies, Vol. 4 Issue. 1, pp. 57-71.

Harshana, P. V. S. (2018), "Work Related Stress: A Literature Review”, Annals of Social Sciences Management studies, Vol. 2, Issue. 3.

Heyder, A. (2019), "Teachers' beliefs about the determinants of student achievement predict job satisfaction and stress", Teaching and Teacher Education, Vol. 86.

Hu, B. Y., Li, Y., Wang, C. and Reynolds, B. L. (2019), “The relation between school climate and preschool teacher stress, The mediating role of teachers' self efficacy", Journal of Educational Administration, Vol. 57 No. 6, pp. 748-767.

Hu, H-H. S., Hu, H-Y. and King, B. (2017), "Impacts of misbehabing air passengers on frontline employees: role stress and emotional labor", International Journal of Contemporary Hospitality Management, Vol. 29, Issue 3. 
Kashif, M., Braganca, E., Awang, Z. and Cyril De Run, E. (2017), "You abuse but I will stay: the combined effects of job stress, customer abuse, and emotional intelligence on employee turnover", Journal of Management Development, Vol. 36, No. 7, pp. 899-914.

Klein, C. J., Weinzimmer, L. G., Cooling, M., Lizer, S., Pierce, L. and Dalstrom, M. (2019), "Exploring burnout and job stressors among advanced practice providers", Nursing Outlook, pp. 1-10.

Kongcharoen, J., Onmek, N., Jandang, P. and Wangyisen, S. (2019), "Stress and work motivation of primary and secondary school teachers", Journal of Applied Research in Higher Education.

Kundaragi, P. B. and Kadakol, A. M. (2015), "Work Stress of Employee: A Literature Review", IJARIIE, Vol. 1, Issue 3.

Li, J. C. M., Cheung, J. C. K. and Sun, I. Y. (2018), "The impact of job and family factors on work stress and engagement among Hong Kong police officers", Policing: An International Journal.

Win, W., Wang, H., Gong, L., Lai, G., Zhao, X., Ding, H. and Wang, Y. (2020), "Work stress, family stress, and suicide ideation: A cross-sectional survey among working women in Shenzhen, China", Journal of Affective Disorders, Vol. 277, pp. 747-754.

Lucia-Palacios, L., Pérez-Lopez, R. and Polo-Redondo, Y. (2020), "Does stress matter in mall experience and customer satisfaction?", Journal of Services Marketing, Vol. 34 No. 2, pp. 177-191.

Manoppo, V. P. (2020), “Transformational leadership as a factor that decreases turnover intention: a mediation of work stress and organizational citizenship behavior", The TQM Journal.

Marques, F. M. F. R., La Falce, J. L., Marques, J. M. R. and De Muylder, C. F. (2020), "The relationship between stress and maturity in knowledge management", International Journal of Organizational Analysis, Vol. 27 No. 5, pp. 1504-1521.

Molek-Winiarska, D. and Molek-Kozakowska, K. (2020), “Are organizations committed to stress management interventions?", Employee Relations: The International Journal.

Moorhead, G \& Griffin, R.W. 1996. Organizational Behavior. New Jersey: Princeton.

1Email: nuria@usm.ac.id

2*Corresponden Author, Email: mugiharsono fe@staff.uns.ac.id 
Naoum, S. G., Herrero, C., Egbu, C. and Fong, D. (2018), "Integrated model for the stressors, stress, stress-coping behaviour of construction project managers in the UK”, International Journal of Managing Projects in Business.

Nappi, I., Ribeiro, G. C. and Cochard, N. (2020), “The interplay of stress and workspace attachment on user satisfaction and workspace support to labour productivity”, Journal of Corporate Real Estate.

Nisar, S. K. and Rasheed, M. I. (2019), "Stress and performance: Investigating relationship between occupational stress, career satisfaction, and job performance of police employees", Journal of Public Affairs.

Oruh, E. S. and Dibia, C. (2020), "Employee stress and the implication of high power distance culture: empirical evidence from Nigeria's employment terrain", Employee Relations: The International Journal.

Pandey, D. L. (2020), "Work Stress and Employee Performance: An Assessment of Impact of Work Stress", International Research Journal of Human Resource and Social Sciences, Vol. 7 Issue. 05, pp. 124-135.

Park, I-J, Kim, P. B., Hai, S. and Dong, L. (2020), “Relax from job, Don't feel stress! The detrimental effects of job stress and buffering effects of co-worker trust on burnout and turnover intention", Journal of Hospitality and Tourism Management, Vol. 45, pp. 559-568.

Park, R., and Jang, S. J. (2017), "Family role overload's relationship with stress and satisfaction", Journal of Managerial Psychology, Vol 32, No. 1, pp. 61-74.

Parveen, M. and Adeinat, I. (2019), "Transformational leadership: does it really decrease work-related stress?", Leadership \& Organization Development Journal, Vol. 40 No. 8, pp. 860-876.

Patel, P. C., and Wolfe, M. T. (2019), "Labor of love? The influence of work-conditions among self-employed and work stress", Journal of Business Venturing Insights, Vol 11.

Peasley, M. C., Hochstein, B., Britton, B. P., Srivastava, R. V. and Stewart, G. T. (2020), “Can't leave it at home? The effects of personal stress on burnout and salesperson performance", Journal of Business Research, Vol. 117, pp. 58-70.

Petek, M. (2018), "Stress among reference library staff in academic and public libraries", Reference Services Review.

\footnotetext{
1Email: nuria@usm.ac.id

2*Corresponden Author, Email: mugiharsono fe@staff.uns.ac.id

P-ISSN: 2580-6084, E-ISSN: 2580-8079
} 
Rabenu, E., Tziner, A. and Sharoni, G. (2017), "The relationship between work-family conflict, stress, and work attitudes", International Journal of Manpower.

Rafida, N., Zairina and Masri, R. (2020), "Describing the Impact of Occupational Stress on Employees Performances During Covid-19 Pandemic”, International Journal of Business Society, Vol. 4 No. 6, pp. 68-73.

Rasool, S. F., Wang, M., Zhang, Y. and Samma, M. (2020), "Sustainable Work Performance: The Roles of Workplace Violence and Occupational Stress", International Journal of Environment Research and Public Health, Vol. 17 No. 912, pp. 1-12.

Revzani, A., and Pouria, K. (2019), "Emotional Intelligence: The key to mitigating stress and fostering trust among software developers working on information system projects", International Journal of Information Management, Vol 48, pp. 139-150.

Ribando, S. J., Slade, C. P. and Fortner, C. K. (2020), "Status, stress and fit: comparing the faculty stress impact of university consolidations", Journal of Organizational Change Management, Vol. 33 No. 2, pp. 289-300.

Saadeh, I. M. and Suifan, T. S. (2020), "Job stress and organizational commitment in hospitals The mediating role of perceived organizational support", International Journal of Organizational Analysis, Vol. 28 No. 1, pp. 226-242.

Sahni, J. (2020), "Impact of COVID-19 on Employee Behavior: Stress and Coping Mechanism During WFH (Work From Home) Among Service Industry Employees", International Journal of Operations Management, Vol. 1, Issue. 1, pp. 35-48.

Sidhu, A. K., Singh, H., Virdi, S. S. and Kumar, R. (2020), "Job stress and its impact on health of employees: a study among officers and supervisors", Journal of Management Development, Vol. 39 No. 2, pp. 125-144.

Saxena, A., Garg, N., Punia, B. K. and Prasad, A. (2020), "Exploring role of Indian workplace spirituality in stress management: a study of oil and gas industry", Journal of Organizational Change Management.

Soelton, M., Lestari, P. A., Ratyuhono, H. A. and Putra, L. (2019), “The Effect of Role Conflict and Burnout Toward Turnover Intention at Software Industries, Work

1Email: nuria@usm.ac.id

2*Corresponden Author, Email: mugiharsono fe@staff.uns.ac.id 62

P-ISSN: 2580-6084, E-ISSN: 2580-8079 
Stress as Moderating Variable", Advances in Economics, Business and Management Research, Vol. 120, pp. 185-190.

Tripathi, N. and Bharadwaja, M. (2018), "Psychological empowerment and stress: role of personality and power distance”, Journal of Indian Business Research.

Walker, A. R. (2020), ““God is my doctor”: mindfulness meditation/prayer as a spiritual well-being coping strategy for Jamaican school principals to manage their workrelated stress and anxiety", Journal of Educational Administration, Vol. 58, No. 4, pp. 467-480.

Wang, C., Pan, R., Wan, X., Tan, Y., Xu, L., Ho, C.S., Ho, R.C. (2020), “Immediate Psychological Responses and Associated Factors during the Initial Stage of the 2019 Coronavirus Disease (COVID-19) Epidemic among the General Population in China", Int. J. Environ. Res. Public Health, Vol. 17.

Wijewardena, N., Samaratunge, R., Kumara, A. S., Newman, A. and Abeysekera, L. (2020), "It takes a family to lighten the load! The impact of family-to-business support on the stress and creativity of women micro-entrepreneurs in Sri Lanka", Personnel Review.

$\mathrm{Wu}, \mathrm{X}$. (2020), "Influence of job stress on job satisfaction among younger bank employees in China The moderating role of guanxi-oriented attitude", Chinese Management Studies, Vol. 14, No. 1, pp. 257-273.

Yang, F-C., Kao, R-H. and Cho, C-C. (2019), "A multilevel study on the causal relationship in association network of work stress: Moderating effects of social support", Policing: An International Journal.

Yao, Z., Zhang, X., Liu, Z. and Luo, J. (2020), "Narcissistic leadership and voice behavior: the role of job stress, traditionality, and trust in leaders", Chinese Management Studies, Vol. 14, No. 3, pp. 543-563.

Yousaf, S., Rasheed, M. I., Hameed, Z. and Luqman, A. (2020), “Occupational stress and its outcomes: the role of work-social support in the hospitality industry", Personnel Review, Vol. 49, No. 3, pp. 755-773.

Zaghini, F., Hochsteinb, B., Proietti, M., Badolammenti, S., Fiorini, J. and Sili, A. (2020), "Occupational stress and its outcomes: the role of work-social support in the hospitality industry", Applied Nursing Research, Vol. 54.

1Email: nuria@usm.ac.id 